\section{Utilization of non-financial business support services to aid development of Micro, Small and Medium Enterprises (MSMEs) in Tanzania}

\author{
Utilización de servicios no financieros de apoyo a las empresas para \\ contribuir al desarrollo de las Pequeñas y Medianas Empresas (PYMEs) \\ en Tanzania
}

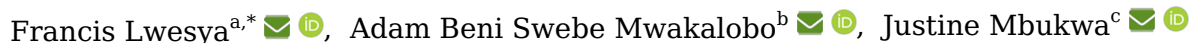

a) Department of Business Administration and Management, The University of Dodoma (Tanzania, United Republic of)

b) Department of Economics and Statistics, The University of Dodoma (Tanzania, United Republic of)

c) Department of Mathematics and Statistics Studies, Mzumbe University (Tanzania, United Republic of)

* Primary Contact: flwesya@yahoo.com (Francis Lwesya)

\begin{abstract}
A variety of factors inhibit the development of MSMEs in African countries, which in turn affects entrepreneurship, job creation and economic transformation. Using cross-sectional data from 250 MSMEs in the Dar es Salaam region, we find in most of the examined variables the positive relationship between the use of non-financial business support services (BDS) and the development of MSMEs in the Dar es Salaam region. However, contrary to expectations, building business linkages and mentoring programs recorded negative relationships with MSMEs development. This is related to restricted capacities stemming from the size of MSMEs compared to large companies and deficiencies in the content of mentoring programs. In addition, the discrepancy between BDS demand and supply as well as the low adoption rate of BDS are associated with the inadequate adaptation of BDS to the needs of MSMEs, high service costs and a lack of qualified service providers. Thus, we argue that the provision of BDS to MSMEs should be demand-driven and that institutions should build on the pre-eminent characteristics of MSMEs when designing business support programs. On the other hand, Government efforts to nurture the development of MSMEs through policies and programs should extend to promoting business linkages between MSMEs and large enterprises.

Keywords: MSME development; non-financial support services (BDS); business development services; weighted average index (WAI) JEL Classification: L25; L26; M13

Resumen

Diversos factores inhiben el desarrollo de las MIPYMES en los países africanos, lo que a su vez afecta al emprendedurismo, la creación de empleo y la transformación económica. Utilizando datos transversales de 250 PYMEs de la región de Dar es Salaam, encontramos que en la mayoría de las variables examinadas existe una relación positiva entre el empleo de Servicios de Desarrollo Empresarial (SDE) y el desarrollo de las PYMEs en la región de Dar es Salaam. Sin embargo, en contra de lo esperado, la creación de vínculos empresariales y los programas de tutoría registraron relaciones negativas con el desarrollo de las PYMEs. Esto está relacionado con las restricciones de capacidad derivadas del tamaño de las PYMEs en comparación con las grandes empresas, además de las deficiencias en el contenido de los programas de tutoría. También, el desajuste entre la demanda y la oferta de SDE, así como la baja tasa de adopción de los SDE, se explican por: los SDE prestados no se ajustan a las necesidades de las PYMEs, a los elevados costes de los servicios y a la escasez de proveedores de servicios cualificados. Por lo tanto, sostenemos que la prestación de SDE a las PYMEs debe estar orientada a la demanda y que las instituciones deben basarse en las características preeminentes de las PYMEs al diseñar los programas de apoyo empresarial. Por otra parte, los esfuerzos del gobierno para fomentar el desarrollo de las PYMEs a través de políticas y programas deberían extenderse a la promoción de los vínculos empresariales entre las PYMEs y las grandes empresas.
\end{abstract}

Palabras clave: desarrollo de las PYMEs; servicios de desarrollo empresarial (SDE); servicios a las empresas; índice medio ponderado (IMP)

Clasificación JEL: L25; L26; M13 


\section{Introduction}

It is widely recognized that the growth of Micro, Small and Medium Enterprises (MSMEs) can play a crucial role in job creation, entrepreneurship development, and economic transformation globally (Abor \& Quartey, 2010; Katua, 2014; Lozano-Reina \& Sánchez Marín, 2019; OECD, 2017; Taraki, 2019). MSMEs are also considered to be a training ground for achieving business competitiveness (Caniëls \& Romijn, 2005; Taraki, 2019). As a result, many developing countries including Sub-Saharan African countries have been pushing and implementing numerous measures that seek to promote the proliferation of MSMEs in their economies (Beyene, 2005; Kongolo, 2010; Obeng \& Blundel, 2015). However, in many African countries MSMEs still appear to suffer from lack of capital for investment to support their activities, lack of information on market opportunities and inefficient technologies, inadequate business training and skills, inability to access advice and consulting services and other related challenges. As such, the utilization of non-financial business support services is increasingly promoted in order to address some of the challenges that MSMEs face in Africa (AsafoAdjei, 2015; Owusu et al., 2017). This is because the utilization of non-financial business support services by MSMEs is associated with innovation and development of new products (Karadal \& Saygin, 2011), improved products, processes and maintenance of customers loyalty (Asafo-Adjei, 2015). Nonetheless, in many MSMEs studies in Africa emphasis is placed on addressing lack of capital for investment which is seen as a major constraint for MSMEs development (Herrington et al., 2009; Musara, 2010; Tillmar, 2016). As such, provision of non-financial support services in form of Business Development Services (BDS) can help tackle the nonfinancial challenges of MSMEs and promote their growth and development via increased competitiveness, improved product quality and enhanced profitability. We refer to non-financial business support services as an array of business development services including but not limited to services like (1) business training, administration and financial management (2) mentoring (3) consultancy and advisory services (4) technology development and transfer (5) business network and linkages promotion (6) marketing skills and information on market opportunities and (7) export assistance (Miehlbradt \& McVay, 2003; Radipere \& Van Scheers, 2014).

In Tanzanian context, there is an increased appreciation of the role of non-financial business support services towards MSMEs development (Mbura \& Merezia, 2015). This in part is due to the reason that MSMEs are seen as a seedbed of entrepreneurship and private sector development. Diao et al. (2018) argue that the fastgrowing MSMEs are important for the private sector growth, development and overall economic transformation in Tanzania. This is illustrated in their study which shows that MSMEs' share for labor productivity growth was around one percentage between 2002 and 2012 . However, despite the importance of MSMEs in Tanzania, many MSMEs fail in nascent stages while others fail few years later after start-up and the general world trend suggests that failure rates are higher in low income countries than in advanced countries. As a result, Schoar (2010), Banerjee et al. (2017) and McKenzie (2015) put emphasis on considering firms heterogeneity in an attempt to promote business development and entrepreneurship in low income countries. Thus, the utilization of non-financial business support services by MSMEs is increasingly seen that can help address the specific needs of MSMEs and hence promote their development. A number of studies show the positive effects of BDS on business development (Okeyo et al., 2014; Mori, 2015; Fowowe, 2017; Ombi et al., 2018). However, most of the studies have concentrated on limited variables such as market access, infrastructure facilities, and procurement services.

The present study incorporates other equally important variables and it examines the supportive policy environment for BDS provision and the state of supply and demand of BDS in the study areas. This enquiry was also motivated by studies of Olomi (2009) and Otieno et al. (2013) who reported the existence of mismatch between BDS supply and demand due to inadequate understanding that BDS services may enhance productivity and better business performance. We use Tanzania as a case study, particularly in Dar-es-salaam region. A cross sectional questionnaire was administered. A total sample of 380 MSMEs was randomly approached but only 250 MSMEs returned the questionnaire and convenience sampling technique was used in order to find representatives of business advisors and Government departments. On the other hand, MSMEs development was captured using a number of yardsticks which are (1) increased profitability (2) improved product quality (3) increased market penetration (4) enhanced managerial efficiency (5) increased competitiveness and (6) enhanced network with large firms.

This study contributes to an understanding of the link between non-financial development services and MSMEs development in Africa. Unlike the previous studies that concentrated on few non-financial BDS, the present study assessed the following non-financial BDS (1) building business linkages with large firms (2) training (3) consultancy and business advisory services (4) marketing assistance (5) technological development and transfer (6) mentoring and (7) Government policy.

The remainder of the paper is organized as follows: Section 2 describes the literature review. Section 3 describes study area and research methodology. Section 4 presents results and discussions. Section 5 presents conclusion and policy implications. 


\section{Literature Review}

\subsection{Theoretical Framework of Non-financial business support services}

The Human Capital Theory. The theory was introduced by Schultz (1961) and was developed further by Becker (1975). The theory posits that education and training is critical for human development and its impact should be assessed in terms of return on investment. The concept of return-on-investment as introduced by Schultz (1961) highlights the cost-benefit analysis of training and education since expenditure on training and education is costly should be considered an investment. Becker (1975) developed the theory by introducing the concept of general-purpose human capital and firm-specific human capital that is widely used by human resource development globally. According to the theory education or training raises the productivity of workers by imparting useful knowledge and skills, hence raising workers future income by increasing their life time earnings (Becker, 1975). A firm requires human capital with the capabilities for identifying and analyzing business development needs and opportunities, these calls for talented human resources with relevant knowledge, competence and other personal attributes. These skill set are usually gained through education, training and experience (O'Sullivan \& Sheffrin, 2007). In this perspective, the theory explains the contribution of non-financial business support services in creating and imparting business education and training to MSMEs owners, workers and operators. This is important since it helps to create awareness among MSMEs and their managers on the need to learn and establish how non-financial business support services facilitate the learning and firm's growth processes.

Contingency Theory. The theory was developed by Fielder (1964) and it explains that situational factors influence decision making and the effectiveness of a leader. According to this theory, "an individual can be an effective leader in one circumstance and an ineffective leader in another one" (Fielder, 1964, pp. 158-159). To be a successful and productive manager or leader, the theory posits that you should be self-aware, objective and adaptable by examining each situation and selecting the effective leadership style. This might be a challenge to some of the MSMEs managers or owners, therefore, the acquisition of non-financial business support services can make MSME owners understand and manage their working environment, market dynamics and business situational circumstances. This may explain the different growth potentials and performance among MSMEs.

The Marketing Mix Theory. Marketing management is one of the key components for any business success. Core to marketing management is the issue of marketing mix which represents a combination of marketing tools and techniques such as product, price, place and promotion (4Ps). According to Mbura and Merezia (2015) the marketing mix "is not a theory of management that has been derived from scientific analysis, but a conceptual framework which highlights the principal decisions that a marketing manager makes in configuring out their offerings to suit customers' needs" (Mbura \& Merezia, 2015, p. 7). This involves decisions such as improving product quality, branding and pricing, informing and attracting new customers and distributing products to final users. These activities may require non-financial business support services to MSMEs in terms of how to apply and manage the marketing mix variables such as product branding and marketing strategies.

Expectancy Theory. Expectancy theory was initially developed by Vroom (1964). The theory argues that a person decides to behave in a certain way based on the expected results in a given situation. According to the theory individuals make choices based on their estimates as to how better the situation will become after a certain decision. The theory is of relevance to the non-financial business service providers in terms of designing the training programs that fit with the requirements of MSMEs. This is because the demand of the non-financial business services will be influenced by the expected benefits after receiving the service. As a result, Mbura and Merezia (2015) argue that it is the duty of service providers to create awareness and persuasion to SMEs on the availability of the services and the benefits to be realized after acquiring the service.

\subsection{Empirical Literature Review}

There is mixed evidence in the literature regarding the impact of BDS on business performance. For example, Ombi et al. (2018) assessed the effect of business development services on small medium enterprises (SMEs) performance in Malaysia. The findings show that while financial support had an effect on SMEs performance non-financial support had no effect on SMEs performance in Sabah, Malaysia. Okeyo et al. (2014) examined the effect of BDS on the performance of SMEs in the manufacturing sector in Kenya; the findings show that BDS did not facilitate market access for SMEs in manufacturing sector but it rather improved procurement services and facilitated access to infrastructure facilities amongst SMEs in the manufacturing sector. Moreover, Krüger (2011) found a negative relationship between market access and SMEs performance in South Africa. On the other hand, Abdullahi et al. (2015) found that BDS in form of education and training in areas of business management, entrepreneurship, financial management and business plan preparation enhanced SMEs owners' management skills and competencies which led to improved business performance. A 
study by Mengstie (2016) shows that BDS in form of market access and input supply affected positively the performance of micro and small enterprises in east Amhara of Ethiopia. However, infrastructure facility, training and technical assistance recorded insignificant effect on performance SMEs.

\subsubsection{Non-financial business support services}

Training of MSMEs owners, managers, employees and other individuals related with MSMEs operation is crucial to foster MSMEs development. Training is needed to impart entrepreneurial, management and business operation skills. Huang (2001) and Brijlal (2011) have indicated that training is critical for organizational and business success. Hence, it is important for the top management to ensure that employees acquire training in different aspects, such as, financial issues (Molina-García et al., 2020). However, since most of the MSMEs are constrained by resources, it is important for Government departments which are involved in MSMEs development to provide training support to MSMEs. In Tanzania, there are initiatives by both the Government and private sector to provide training to MSMEs; however, lack of requisite skills set remains one of the key challenges amongst MSMEs in Tanzania (Olawale \& Garwe, 2010). We examined to what extent the training provided by Government departments lead to MSMEs development and whether those training address the needs of MSMEs. Thus, it is hypothesized that:

\section{H1: Training has significant effects on MSMEs development in Tanzania.}

Mentoring is perceived as an informal transfer of skills and knowledge through an act of guiding and grooming. The mentorship is normally performed by an individual who has exposure, wisdom, knowledge, skills and experience to a less knowledgeable one (Bozeman \& Feeney, 2007). MSMEs need to be guided and groomed through mentorship in order to achieve growth and development. The ultimate goal of mentorship is skills transfer. Von Broembsen et al. (2005) indicate that only 35\% of youths between the ages of 25-44 stated that they had skills for business start up in Tanzania. This informs that MSMEs mentorship programs could be of a major help to emerging MSMEs. Thus, it is hypothesized that:

\section{H2: Mentoring programs have significant effects on MSMEs development in Tanzania.}

Consultancy and business advisory services are one of the sources of the reliable business ideas and information which may enable small businesses to cope with the existing and emerging challenges in the business environment. These services are aimed at providing guidance, advice and direction to MSMEs. MSMEs face a number of challenges such as starting a business for wrong reason, lack of critical skills, inadequate knowledge of the market, inadequate business planning skills, shortage of financial literacy and lack of financial skills to secure funding (Matshonisa Seeletse \& Tshepo MaseTshaba, 2016). In this context, advisory services are needed to help MSMEs address the survival and growth challenges (Bozeman \& Feeney, 2007). Thus, it is hypothesized that:

\section{H3: Consultancy and advisory services have significant effects on MSMEs development in Tanzania.}

Technological Development and Transfer. The adoption of modern and appropriate technology is an important driver of MSMEs development as it is one of the sources of competitive edge. This is because in today's open market economy where countries have embraced globalization policies, the level of competition is high. In this context, the survival of MSMEs depends on the technology use and innovation. However, many MSMEs lack resources and qualified staff to make this possible. As result, technological advice has been instrumental in helping MSMEs minimize access to technology challenges. In Tanzania, institutions like University of Dar es salaam Entrepreneurship Centre (UDEC), Small Industries Development Organization (SIDO) provide technological advice and support programs through business incubation centers for MSMEs. However, there is limited application of these opportunities and technology advice due to challenges related to lack of information, lack of relevant technologies for MSMEs and financial challenges to acquire the relevant technologies. As such, Bozeman and Feeney (2007) show that it is important to help MSMEs address these challenges. We examine the influence of advice and technological support on MSMEs development. Thus, it is hypothesized that:

H4: Technological advice and transfer have significant effects on MSMEs development in Tanzania.

Marketing Assistance. Studies of O’Dwyer et al. (2009) and Price et al. (2013) have shown that market access is very important for organizations to excel in business. MSMEs face challenges related with marketing both in local and international markets due to shortage of marketing resources and skills and increasing global competition. This stems from lack of information on market opportunities, inadequate knowledge on branding, product packing, entry in global markets etc. In this perspective, being able to market products of a firm is a determinant of a firm's success. Non-financial support inform of marketing assistance is important for MSMEs to overcome local and global marketing challenges. According to Price et al. (2013) management of market by responding to competition through creativity, product improvement, and product branding and other related innovations are critical for business survival and growth. Hence, MSMEs require business support services in 
form of marketing assistance in order to address survival and growth challenges in the market. Thus, it is hypothesized that:

H5: Marketing assistance has significant effects on MSMEs development in Tanzania.

Business Linkages. Building of business linkages and networks is one of the important areas that can stimulate MSMEs success. Given the challenges of resources that MSMEs are facing, business linkages and networks can help MSMEs overcome constraints related to access to market information and opportunities, and access to technology. MSMEs can develop linkages with large firm and serve as input suppliers of large firms; this help MSMEs to overcome survival and growth challenges. Jenkins et al. (2007) argue that business linkages help to promote local integration thereby facilitating increasing access to skills and knowledge to start up MSMEs. Thus, it is hypothesized that:

H6: Building of business linkages have significant effects on MSMEs development in Tanzania.

The Role of Government Policy. The Government plays an important role in fostering the development of MSMEs in any country. The Governments can provide direct support and formulate policies that are conducive for the growth and development of MSMEs thereby helping MSMEs to overcome the growth and survival challenges (Hitchins, 2002; Rogerson, 2006; Herrington et al., 2009). However, it is stated that some of the policies formulated by the Government are unfriendly to private sector development (Juma \& Said, 2016; Mkenda \& Rand, 2020; Lwesya, 2021). It is important that the policies formulated by Government do not create uncertainty, and act as barriers to MSMEs development. Thus, it is hypothesized that:

H7: Government policy has significant effects on MSMEs development in Tanzania.

Figure 1. A Conceptual Framework Model

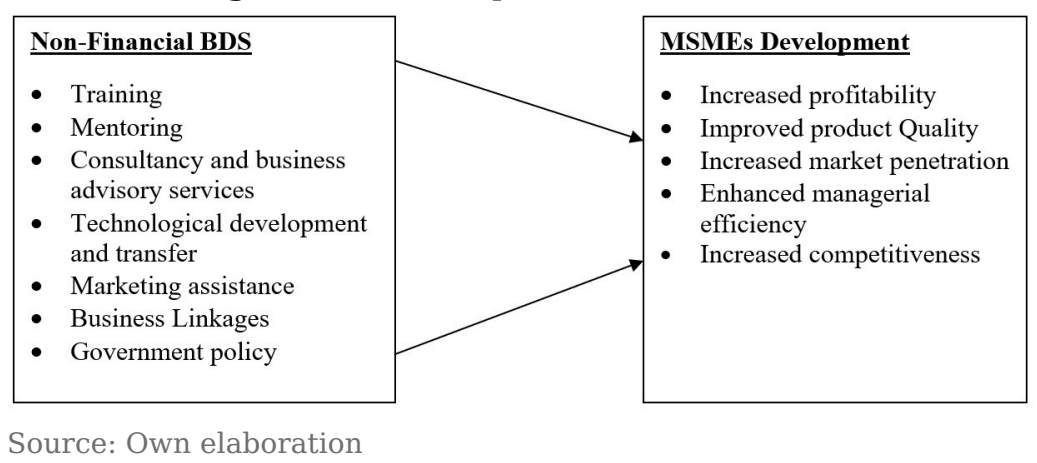

Figure 1 is the conceptual framework model which shows the nexus between the non-financial support services and MSME development as synthesized in the literature review.

\section{Study Area and Research Methodology}

The area of study was Dar-es-salaam region in Tanzania. The region was selected due to plethora of MSMEs and the presence of business development support services (BDS) to MSMEs owners. Globally, there is no consensus on the yardsticks used to define MSMEs (Beck et al., 2005). Diverse criteria related to a country's environment are used. This research uses a definition of SME as introduced by the SMEs development Policy of Tanzania (Table 1).

Table 1. MSMEs Categories

\begin{tabular}{|l|l|l|l|}
\hline \multicolumn{1}{|c|}{ No Category } & \multicolumn{1}{c|}{ Employees } & \multicolumn{1}{c|}{ Capital Invested in Machinery (Usd) } \\
\hline 1 & Micro enterprise & $1-4$ & 2,000 usd \\
\hline 2 & Small enterprise & $5-49$ & Above 2,000 usd. To 85,000 usd \\
\hline 3 & Medium enterprise & $50-99$ & Above 85,000. To 340,000 usd \\
\hline 4 & Large enterprise & 100 and above & Above 340,000 usd \\
\hline
\end{tabular}

\subsection{Current status of MSMEs in Tanzania}

MSMEs sector has continued to play an important role in the economic transformation in Tanzania via creation of employment opportunities, source of creativity and innovation and its contribution to GDP. According to the National Baseline Survey Report for Micro, Small, and Medium Enterprises in Tanzania, MSMEs contributed about 27 percent to Tanzania's GDP in 2010 (Ministry of Trade and Industry, 2012; Diao et al., 2018). Diao et al. (2018) further estimated the contribution of MSMEs showing that the value-added of all MSMEs accounted 
for 32.4 percent of national private non-agricultural GDP in 2010. The MSMEs contribution to manufacturing value-added was around 25 percent concentrating in beverages, food processing, textile, wood processing, furniture, and building materials. Moreover, using Tanzania's Annual Survey of Industrial Production (ASIP) for 2008 and 2009 which are the two available rounds of ASIP, Diao et al. (2018) show that the total value added of the six manufacturing subsectors that was contributed by small firms in the informal sector was higher than that of their counterpart formal firms.

A cross sectional questionnaire was administered. A sample of 380 MSMEs was randomly selected but only 250 MSMEs returned the questionnaire. The MSMEs were drawn from sectors of Agriculture (50), Manufacturing (100) and Services (100). Convenience sampling technique was used in order to find representatives of Business Advisors. A total of 10 Consultant and Business Advisors and 5 Government Agencies were approached and administered with questionnaires. We distributed questionnaires and collected information from the MSMEs owners and managers so as to get tips of the demand side of the non-financial business support services. This was important to understand the extent of service utilization, challenges and what needs to be done by service providers in order to improve the services. On the other hand, business advisors and Government departments were important on the supply side of the non-financial business support services. They provided information on the types of non-financial support services provided and the extent of their utilization, challenges faced by MSMEs when acquiring the services and the supportive policy environment in place. However, in assessing the nexus between the utilization of non-financial support services and MSMEs development, we used data collected from MSMEs in empirical analysis and the data that was collected from business advisors and Government departments enriched the empirical findings through descriptive analysis.

In terms of the non-financial support services offered, the questionnaires were based on a five point likert scale as follows; 5 = Very often, $4=$ Often, $3=$ Average, $2=$ Not often, $1=$ Not at all. On the other hand, regarding the perceptions of MSMEs owners, business advisors (business consultants) and Government officials with regard to non-financial support services, the questionnaires were based on a five-point likert scale as follows: $5=$ Highly beneficial, $4=$ Beneficial, $3=$ Neutral, $2=$ Less beneficial, $1=$ Not beneficial at all. In the same way, the questions concerning the challenges were based on a five-point likert scale as follows: 5 = Highly challenging, $4=$ Challenging, $3=$ Neutral, $2=$ Less challenging, $1=$ Not challenging at all. The descriptive analysis was used to examine the perceptions of MSMEs owners, business advisors (business consultants) and Government officials regarding provision of non-financial support services. Method of Analysis is the weighted average index (WAI) which was used to examine farmers' perception of the economic benefits of excreta use in southern Ghana (Cofie et al., 2010).

The WAI formula followed:

$$
W A I=\sum \frac{S_{i} F_{i}}{N}(1)
$$

Where:

- WAI is $(0 \leq W A I \leq 1)$

- $F_{i}=$ Is the frequency of response

- $S_{i}=$ Is the scale value assigned at $i$ priority, and

- $N=$ Is the total number of responses.

\section{Results}

\subsection{Demographic of the Sampled Population}

The general demographic of the sampled population has been given in Table 2. The table shows that a large number of MSMEs business owners were below the age of 50 years. In terms of the education, the majority had secondary education (109 or $43.6 \%$ ) and primary education (72 or $28.8 \%$ ) respectively. This confirms the need for training to MSMEs owners.

The Majority of the MSMEs were in service (100 or 40\%) and manufacturing sectors (100 or $40 \%$ ), only (50 or $20 \%$ ) were engaging in agricultural trade. This is in consistent with results of Diao et al. (2018) who reported recently the rise of employment opportunities in service and manufacturing sectors in Tanzania. Most of the MSMEs (214 or $85.6 \%$ ) were operating under sole proprietorship. This is linked to the popularity of sole proprietorship and its simplicity in starting the business (Cronje et al., 2004). However, Woldie et al. (2008) warn that sole proprietorship is a risky form of business ownership. This in part justifies the need for nonfinancial business development services training to sole proprietors.

Regarding the demographic profile of business consultants and advisors and Government departments' representatives, the majority had university education (8 or $80 \%$ ) and college education (2 or 20\%) 
respectively. This is an indication that most of the business advisors are in young age and have university knowledge which suggests that they are well informed of non-financial business support services. Most of the business advisors have served more than 50 MSMEs owners and all have appropriate and relevant knowledge of the non-financial business development services (10 or 100).

Table 2. Demographics of the Sampled Population

\begin{tabular}{|c|c|c|c|c|c|c|c|}
\hline \multirow[t]{2}{*}{ No } & \multirow[t]{2}{*}{ Details } & \multicolumn{2}{|c|}{ Demographics of MSMEs } & \multicolumn{2}{|c|}{$\begin{array}{l}\text { Demographics of Business } \\
\text { Advisors }\end{array}$} & \multicolumn{2}{|c|}{$\begin{array}{l}\text { Demographics of } \\
\text { representatives from } \\
\text { Government Agencies }\end{array}$} \\
\hline & & Frequency & Percentage & Frequency & Percentage & Frequency & Percentage \\
\hline \multirow[t]{6}{*}{1} & Age & & & & & & \\
\hline & $15-30$ & 58 & 23.2 & 1 & 10.0 & & \\
\hline & $31-40$ & 72 & 28.8 & 4 & 40.0 & & \\
\hline & $41-50$ & 60 & 24.0 & 3 & 30.0 & 2 & 40.0 \\
\hline & $51-60$ & 25 & 10.0 & 2 & 20.0 & 3 & 60.0 \\
\hline & 60 and above & 35 & 14.0 & & & & \\
\hline \multirow[t]{3}{*}{2} & Gender & & & & & & \\
\hline & Male & 148 & 59.2 & 6 & 60.0 & 4 & 80.0 \\
\hline & Female & 102 & 40.8 & 4 & 40.0 & 1 & 20.0 \\
\hline \multirow[t]{5}{*}{3} & Marital status & & & & & & \\
\hline & Single & 94 & 37.6 & 3 & 30.0 & & \\
\hline & Divorced & 34 & 13.6 & & & & \\
\hline & Married & 102 & 40.8 & 7 & 70.0 & 5 & 100.0 \\
\hline & Widow & 20 & 8.0 & & & & \\
\hline \multirow[t]{4}{*}{4} & Sector of Business O & & & & & & \\
\hline & Manufacturing & 100 & 40.0 & & & & \\
\hline & Service & 100 & 40.0 & & & & \\
\hline & Agriculture & 50 & 20.0 & & & & \\
\hline \multirow[t]{4}{*}{5} & Forms of Business $\mathrm{O}$ & & & & & & \\
\hline & Sole proprietorship & 214 & 85.6 & & & & \\
\hline & Partnership & 32 & 12.8 & & & & \\
\hline & Limited Liability & 4 & 1.6 & & & & \\
\hline \multirow[t]{5}{*}{6} & Education & & & & & & \\
\hline & Primary & 72 & 28.8 & & & & \\
\hline & Secondary & 109 & 43.6 & & & & \\
\hline & College & 54 & 21.6 & 2 & 20.0 & 1 & 20.0 \\
\hline & University & 15 & 6.0 & 8 & 80.0 & 4 & 80.0 \\
\hline \multirow[t]{4}{*}{7} & Number of employee & & & & & & \\
\hline & Below 5 & 98 & 39.2 & & & & \\
\hline & Between 5-49 & 106 & 42.4 & & & & \\
\hline & Between 50-99 & 46 & 18.4 & & & & \\
\hline \multirow[t]{4}{*}{8} & Annual turnover of $b$ & & & & & & \\
\hline & Less that 2200 USD & 96 & 38.2 & & & & \\
\hline & $\begin{array}{l}\text { Between 2200-8600 } \\
\text { USD }\end{array}$ & 119 & 47.5 & & & & \\
\hline & Above 8600 USD & 36 & 14.3 & & & & \\
\hline \multirow[t]{3}{*}{9} & Awareness of Non-Fi & B Business De & pment service & & & & \\
\hline & Yes & 197 & 78.8 & & & & \\
\hline & No & 53 & 21.2 & & & & \\
\hline \multirow[t]{3}{*}{10} & Use of Non-Financial & ess Developn & services & & & & \\
\hline & Yes & 124 & 49.6 & & & & \\
\hline & No & 126 & 50.4 & & & & \\
\hline \multirow[t]{3}{*}{11} & Importance of non-fi & 1 business ser & $\mathrm{s}$ to MSME de & oment & & & \\
\hline & Yes & 147 & 58.8 & & & & \\
\hline & No & 103 & 41.2 & & & & \\
\hline 12 & \multicolumn{3}{|c|}{$\begin{array}{l}\text { Number of customers served by Business Advisors (Above } \\
50 \text { ) }\end{array}$} & 10 & 100.0 & & \\
\hline 13 & \multicolumn{3}{|c|}{$\begin{array}{l}\text { Awareness of the non-financial business development } \\
\text { services }\end{array}$} & 10 & 100.0 & & \\
\hline
\end{tabular}

Source: Own elaboration

In assessing the awareness of non-financial business development services among MSMEs, it was found that $197(78.8 \%)$ MSMEs owners were aware of the non-financial business development services while only 53 $(21.2 \%)$ were not aware of non-financial support services. However, only 124 (49.6\%) use the non-financial support services while 126 (50.4) do not use the services. In terms of the importance of the non-financial services, the majority 147 (58.8\%) recognized the importance of acquiring and utilizing non-financial support services to help them grow and develop their businesses while 103 (41.2\%) did not see the importance of nonfinancial support services in their businesses. 


\subsection{The Perceptions of MSMEs owners, business advisors and Government officials of non-financial support services}

Table 3 presents the views of MSMEs owners, business advisors (business consultants) and Government officials with regard to non-financial support services provided. From the respondents, the Weighted Average Index (WAI) was considered very strong for the factors of consultancy and business advisory services (WAI=2.97), on the job training (WAI=2.58), marketing assistance $(\mathrm{WAI}=2.40)$ and technological development and transfer (WAI=2.27). This shows that consultancy and business advisory services, training and market assistance are among the regular non-financial support services provided to MSMEs in Dar es salaam region. In the same vein, building business linkages and mentoring recorded weak WAI.

On the other hand, business advisors indicated that consultancy and business advisory services (WAI=7.50), on the job training (3.90) and marketing assistance (WAI=3.80) were the most non-financial support services provided. These results are in line with the perceptions of MSMEs owners. In contrast, Government officials indicated that on the job training (WAI=4.40), consultancy and business advisory services $(\mathrm{WAI}=3.60)$ and technological development and transfer $(\mathrm{WAI}=3.30)$ were the most non-financial services provided to MSMEs in Dar es salaam region. This is linked to the availability of Government departments and institutions that support the development of MSMEs in Dar es salaam region such as Small Industries Development Organization (SIDO), Tanzania Trade Development Authority (TANTRADE) and few Government financial institutions which are aware of the need of business development services and have incorporated them in their core activities particularly by providing training, advisory services and helping in transfer of technology to MSMEs.

Table 3. The perceptions of MSMEs owners, business advisors and Government officials on non-financial business support services

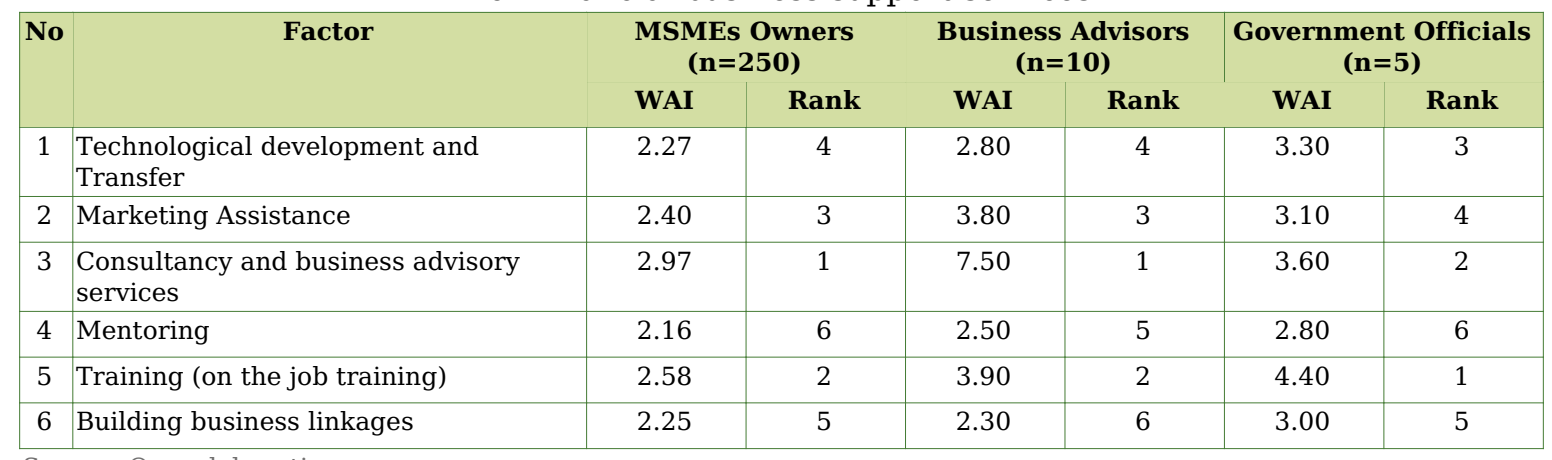

Source: Own elaboration

\subsection{The influence of non-financial business support services on MSMEs Development}

In examining the influence of non-financial support services on MSME development, we conducted a multiple regression analysis (Table 4 ). The regression equation was given as follows:

$$
y=\beta_{0}+\beta_{1} X_{1}+\cdots+\beta_{n} X_{n}+\varepsilon(2)
$$

Where

- $y=$ Dependent variable

- $\beta_{i}=$ Coefficients

- $X_{i}=$ Independent variables

- $\varepsilon=$ error term

Dependent variable was MSMEs development. This was captured by using variables such non-financial BDS increased profitability, improved product quality, increased market penetration, enhanced managerial efficiency, increased competitiveness and enhanced network with large firms. The respondents were asked to rate how their profitability, product quality, market penetration managerial efficiency, competitiveness and network with large firms changed after receiving non-financial support services in the past two years. The fivepoint likert scale was used to capture the responses.

Independent variables. Non-financial business development services was an independent variable which was captured by training, mentoring, consultancy and business advisory services, technological development and transfer, marketing assistance, business linkages and Government policy. The five-point likert scale was used to capture the responses. 
Control variables. The study incorporates three control variables which are firm size, firm age, and firm sector. Control for firm size was important partly due to the reason that micro and small firms face many challenges which calls for more support compared to medium or large firms. Firm age was important to capture the years of business experience among MSMEs. The firm sector was used to identify the distribution of firms in various sectors of the economy. The firms were found to be distributed in three major sectors which are agriculture, service and manufacturing.

Table 4. Model Summary and Multiple regression results (a)

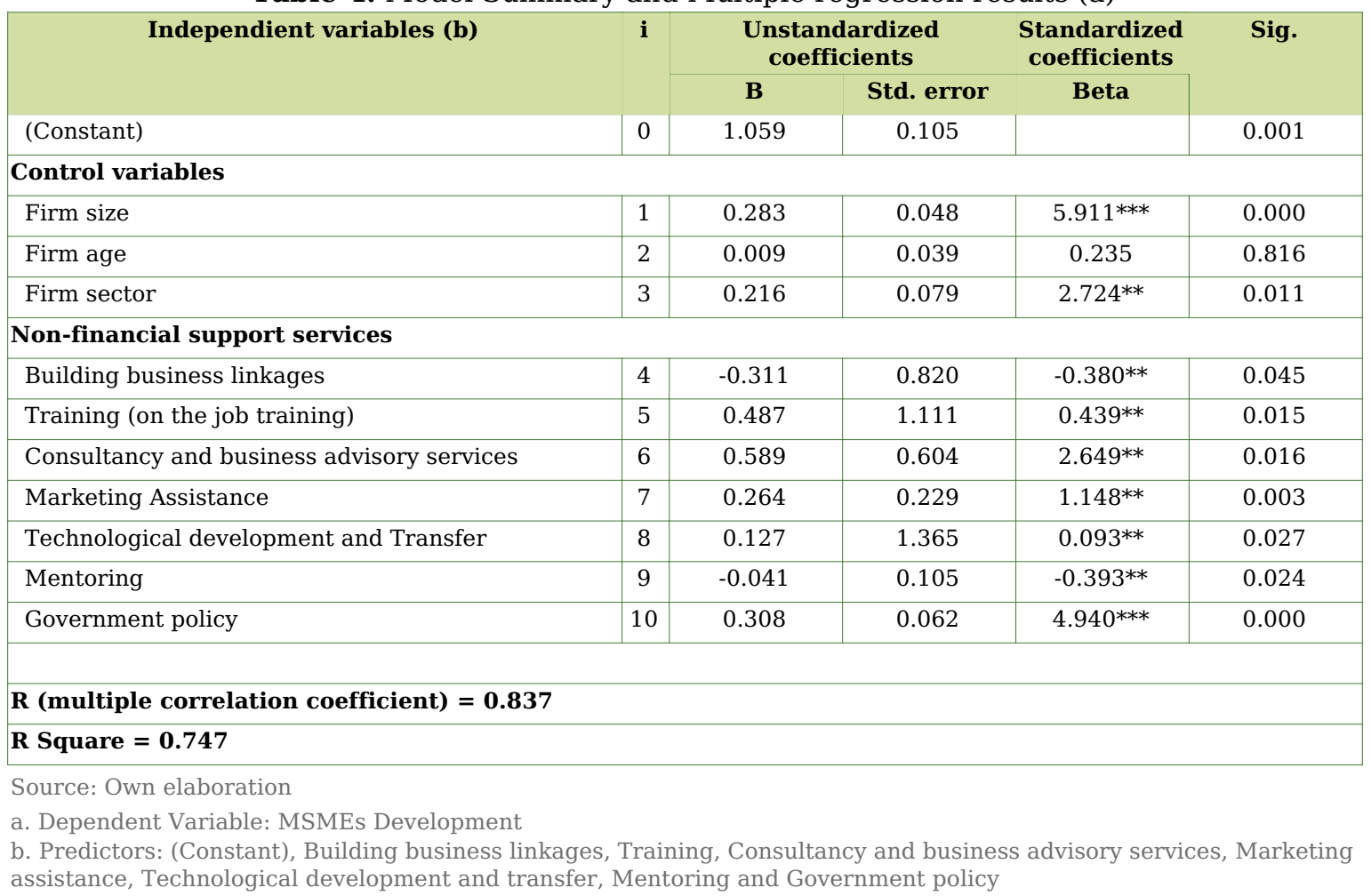

From the results it is evident that non-financial business support services recorded a moderate relationship with MSMEs development and the result of $R^{2}$ value suggests that 75\% variation of MSMEs development could be explained by non-financial business support services.

In terms of the individual non-financial support services, consultancy and business advisory services had coefficients of estimate which was significant $\left(\beta_{6}=0.589, p<0.0158\right)$. This means that there was up to 0.589 increases in MSME performance for each unit increase in consultancy and business advisory services to MSMEs. Several studies have indicated that MSMEs face a number of challenges including inadequate training, shortage of capital and an anti-entrepreneurial spirit in Tanzania (Mashenene \& Rumanyika, 2014; Isaga, 2019). This suggests that provision of non-financial support in form of consultancy and business advisory services is expected to enhance MSME performance. Similarly, training (on the job training) had a significant relationship with MSMEs development $\left(\beta_{5}=0.487, p<0.015\right)$. There was up to 0.487 increases in MSME performance for each unit increase in training to MSMEs. For example, studies of Anderson (2017) and Nyangarika (2016) have shown that limited resources and lack of managerial and operation skills, limited market information, inadequate access to appropriate technology and finance are among the barriers to MSMEs development in Tanzania. This implies that non-financial support services in form of on-job training would have a significant impact on MSME performance.

In the same vein, the findings indicated that marketing assistance had a significant relationship with MSMEs development $\left(\beta_{7}=0.264, p<0.003\right)$. This means there was up to 0.264 increases in MSME performance for each unit increase in marketing assistance to MSMEs. Swai (2017) indicated that access to the formal markets and markets, poor technology and lack of certification are among the barriers facing MSMEs in Tanzania, and in view of this non-financial support in form of marketing assistance could enhance MSMEs performance. Moreover, technological development and transfer indicated a positive relationship with MSMEs development $\left(\beta_{8}=0.127, p<0.027\right)$ suggesting that there was up to 0.127 increases in MSME performance for each unit increase in technological development and transfer to MSMEs. Inaccessibility to appropriate and relevant technology is among the challenges facing MSMEs in Dar es salaam region, currently, there are initiatives by both the public and private institutions to support MSMEs. For example, SIDO apart from providing training and advisory services have been assisting MSMEs access various equipment, machines, and incubation technologies at affordable prices. This has helped in some ways MSMEs to improve their products quality. 
On the other hand, in contrast to expectations, building business linkages recorded a negative relationship with MSMEs Development $\left(\beta_{4}=-0.311, p<0.045\right)$. This means that there was up to 0.311 decrease in SME performance for each unit increase in building business linkages. The divergent relationship may be due to inadequate capacity stemming from the small size of MSMEs compared with their counterpart large firms and hence non-realization of expected results. Kweka and Sooi (2020) show that business linkages between SMEs and large firms are weak in Tanzania and they argue that establishing business linkages is influenced by firm's level of production capacity, training, participation in exporting, and technology partnerships.

In the same way, mentoring had a negative relationship with MSMEs Development $\left(\beta_{9}=-0.041, p<0.024\right)$. This implies that there was up to 0.041 decrease in MSME performance for each unit increase in mentoring. The divergent relationship might be a result of the content of mentorship provided and the negative implications it had on MSMEs performance.

Lastly, Government policy had a significant relationship with MSMEs development $\left(\beta_{10}=0.308, p<0.000\right)$. This means there was up to 0.308 increases in MSME performance for each unit in improved government policy to MSMEs. A number of studies have shown that unfriendly business environment as a result of poor tax policies, restrictive entrance procedures and cumbersome legal and regulatory frameworks hinder the growth and development of MSMEs (Mpunga, 2016; Juma \& Said, 2016; Mkenda \& Rand, 2020; Lwesya \& Ismail, 2021). Thus, strengthening the business environment through appropriate and friendly business policies promotes the development of private sector.

\subsection{Complementary descriptive analysis}

In terms of how MSMEs perceive the benefits of non-financial support services (Table 5), a strong WAI was recorded for increased competitiveness (WAI=3.20), improved product quality $(\mathrm{WAI}=2.92)$, increased profitability (WAI=2.89) and enhanced managerial efficiency (WAI=2.66). This finding reveals that MSMEs owners are aware of the importance of non-financial support services and that it is critical in the overall development of their small businesses. However, MSMEs had weak perceptions that non-financial support services enhanced network with large firms. On the other hand, business advisors indicated strong WAI for increased competitiveness (WAI $=4.40)$, improved product quality $(4.20)$ and increased profitability $(\mathrm{WAI}=3.80)$. This generally shows that here is a positive correlation between non-financial support services and MSMEs improved performance.

Table 5. Benefits of non-financial support services to MSMEs

\begin{tabular}{|c|l|c|c|c|c|}
\hline \multirow{2}{*}{ No } & \multicolumn{2}{|c}{ Factor } & MSMEs Owners (n=250) & \multicolumn{2}{c|}{ Business Advisors (n=10) } \\
& & WAI & Rank & WAI & 5 \\
\hline 1 & Increased market penetration & 2.58 & 5 & 3.40 & 6 \\
\hline 2 & Enhanced network with large firms & 2.50 & 6 & 2.40 & 2 \\
\hline 3 & Improved product Quality & 2.92 & 2 & 4.20 & 3 \\
\hline 4 & Increased profitability & 2.89 & 3 & 3.80 & 1 \\
\hline 5 & Increased competitiveness & 3.20 & 1 & 4.40 & 3.70 \\
\hline 6 & Enhanced managerial efficiency & 2.66 & 4 & & 4 \\
\hline
\end{tabular}

Source: Own elaboration

In terms of the challenges to accessing appropriate non-financial support services (Table 6), failure of nonfinancial support services to fit with the needs of MSMEs (WAI=3.78), high cost of services (WAI=3.29), Shortage of qualified providers (WAI=2.87) and limited access to information (WAI=2.54) recorded strong WAI. This finding highlights that MSMEs have unique and specific needs for non-financial assistance that business consultants must consider when designing their non-financial support services if their services to MSMEs are to be productive and successful. IFC (2010) argues that smallness of MSMEs confers a disadvantage; this is because business owners or managers have to perform a wide range of duties compared to their large firms' counterparts. This calls for diverse skills set that MSMEs managers or owners may not have particularly in developing countries.

High cost of services is another challenge in acquiring non-financial support services. In view of this, Ernst and Young (2009) posits that in expensive non-financial support services the majority of the SMEs do not seek to invest in them. Similarly, shortage of qualified business service providers seems to have affected the performance of MSMEs negatively. This in part can be explained by the reason that existing service providers tend to provide generalized solutions to identified problems (Owusu et al., 2017). It was also found that while non-financial support services are important to the development of MSMEs, limited access to information about their availability and usage is one of the reasons why they are not used. This may be related to the fact that some Government institutions and business consultants from the private sector do not provide regular information about them, which in turn reduces their use. On the other hand, though lack of monitoring and evaluation received the least weight $(\mathrm{WAI}=2.32)$, it is vital to receive feedback from MSMEs on the impact of 
non-financial support services provided. This is especially important to Government departments and institutions to nurture MSMEs in order to help them achieve growth and competitiveness through policy reviews and other regulatory measures.

Table 6. Challenges in providing non-financial support services from the

\begin{tabular}{|c|c|c|c|}
\hline & e oI I & & \\
\hline \multirow[t]{2}{*}{ No } & \multirow[t]{2}{*}{ Factor } & \multicolumn{2}{|c|}{ MSMEs Owners $(n=250)$} \\
\hline & & WAI & Rank \\
\hline 1 & Shortage of qualified providers & 2.87 & 3 \\
\hline 2 & High cost of services & 3.29 & 2 \\
\hline 3 & Limited access to information & 2.54 & 4 \\
\hline 4 & $\begin{array}{l}\text { Failure of non-financial support services to fit with the } \\
\text { needs of MSMEs }\end{array}$ & 3.78 & 1 \\
\hline 5 & $\begin{array}{l}\text { Lack of monitoring and evaluation on the impact of the } \\
\text { services received }\end{array}$ & 2.32 & 5 \\
\hline
\end{tabular}

In terms of ranking the non-financial support services that MSMEs would like to receive (Table 7), business management skills in areas of human resource and financial literacy (WAI=4.38), quality management (WAI=4.02), business creation and start up (WAI=3.69), and risk management (WAI=3.23) recorded strong WAI. Regarding business management skills, Keasey and Wastson (1993) show that small firms' owners are constrained by inadequate skills and experience to make their businesses successful. Moreover, IFC (2010) argues that low levels of financial literacy cannot help SMEs sufficiently make a critical assessment of the different financing choices and decide on the appropriate modality for their businesses. Thus, improving financial knowledge and management training may have a positive impact on MSMEs development. On top of that, quality management is very important particularly in the modern competitive business environment, most of MSMEs indicated that maintaining quality is at the center to enable them survive, grow and remain in the market. For example, Nkwabi and Fallon (2020) indicated that support from the Government to enable SMEs use experts and acquire modern technologies to enable them produce quality products is critical in the food manufacturing firms in Dar es salaam region. Therefore, non-financial support services that address the quality management issues are preferred amongst MSMEs owners in Dar es salaam region.

Similarly, business creation and startup had strong WAI (3.69). According to the MSMEs baseline survey (2010), only 5\% of MSMEs had Tax Identification Numbers (TIN) and only 4\% were registered with Business Regulation and Licensing Agency (BRELA). This suggests that most of the MSMEs are still operating informally. Thus, non-financial business support service that address business creation and start up will help most MSMEs to graduate from informal to formal status. Moreover, risk management is another non-financial business support area that received relatively strong preference (WAI=3.23). According to Raghavan (2005) risk mitigation seeks loss reduction while maximizing profitability. Studies indicate that MSMEs are exposed to multiple risks such as failure of customers to pay their debt, fraud, theft, fire disaster, fluctuation in prices of raw material, interest rate risk, e-business and technological risks, among others. These risks if not mitigated on time ultimately lead to business failure. Non-financial support services in form of risk mitigation measures will help MSMEs take proactive measures to identify, analyze, and control risks. On the other hand, three factors had lower preference, these are technology development and transfer (WAI=2.98), network development in form of building linkages with large firms (2.73) and export assistance (WAI=2.13).

Table 7. Preference of non-financial support services by MSMEs

\begin{tabular}{|c|l|c|c|}
\hline No & \multicolumn{1}{|c|}{ Factor } & \multicolumn{1}{|c|}{ MSMEs Owners (n=250) } \\
& \multicolumn{1}{|c|}{ Wank } \\
\hline 1 & Risk management & 3.23 & 4 \\
\hline 2 & $\begin{array}{l}\text { Business management skills (Human resource \& } \\
\text { financial management) }\end{array}$ & 4.38 & 1 \\
\hline 3 & Quality management & 4.02 & 2 \\
\hline 4 & Business creation and start up & 3.69 & 3 \\
\hline 5 & Technology development and transfer & 2.98 & 5 \\
\hline 6 & Network development (linkages with large firms) & 2.73 & 6 \\
\hline 7 & Export assistance & 2.13 & 7 \\
\hline Source: Own elaboration & & \\
\hline
\end{tabular}




\section{Discussion of the study findings}

The study examined the association between the utilization of non-financial business development services and MSMEs development. The study presents mixed evidences. For example, variables such as training, consultancy and advisory services, marketing assistance, technological development and transfer and Government policy were found to be associated with MSMEs development in Dar es salaam region. This is in consistent with the theories and the studies of Abdullahi et al. (2015) and Mengstie (2016) who found that BDS in form of training and market access respectively had a significant impact on SMEs development. However, Mengstie (2016) found insignificant relationship between training and technical assistance and SMEs performance in Ethiopia. Generally, the findings of the present study contradict with the findings of Ombi et al. (2018) who did not find any significant association between non-financial business development services and SMEs performance in Malaysia. Similarly, Okeyo et al. (2014) found that BDS did not facilitate market access for SMEs in the manufacturing sector but it rather improved procurement services and facilitated access to infrastructure services in Kenya. In addition, Krüger (2011) reports the negative association between market access and SMEs performance in South Africa.

The present study also found that the variables such as building business linkages and mentoring are negatively associated with MSMEs development. These inverse relationships may be related to the informality and low capability of MSMEs to forge and adequately gain from established business relationships with large firms. This in part would require addressing the supply side constraints of MSMEs and Government intervention in this regard would be essential. UNCTAD (2020) argues that successful business linkage programs depend on effective public-private partnerships, clear objective for private sector development and well-defined roles and responsibilities of different stakeholders to the programs. Similarly, the content of the mentorship program might be the reason for the inverse relationship between mentoring and MSMEs performance. Peel (2004) insists that pre-eminence of MSME's culture is a basic element that should be incorporated within any mentoring program so as to be successful. The findings highlight that the effects of non-financial development services on business performance are not evenly distributed among firms in different countries. This study associates this situation with a number of factors including heterogeneity of firms, differences in local conditions, diversity in the level of support, and differences in Government policies.

\section{Conclusion and Policy implications}

Contributions of the work for the investigation. This study contributes to an understanding of the link between non-financial development services and MSMEs development in Africa. Unlike the previous studies that focused on few BDS like market access, infrastructure facilities, training and procurement services, the present study synthesized from the literature and assessed other equally important non-financial BDS variables such as building business linkages, training, consultancy and business advisory services, marketing assistance, technological development and transfer, mentoring and Government policy. The study found that training, consultancy and business advisory services, marketing assistance, technological development and transfer and Government policy to be positively associated with MSMEs development in Tanzania. However, in contrast to expectations, building business linkages and mentoring recorded negative relationships with MSMEs development. On the other hand, based on the perceptions of MSMEs owners and managers the mismatch between BDS supply and demand and low adoption rate of BDS services is due to failure of nonfinancial support services provided to fit with the needs of MSMEs, high cost of services and shortage of qualified service providers.

Contributions for practice (Professionals, Government, and Managers). This study contributes to an understanding and appreciation of the role of non-financial business development services in the development of MSMEs for professionals, Governments and managers. Consistent with the expectancy theory, managers need to know what type of skills, technology or mentoring programs are needed in their organizations before embarking on a non-financial BDS programme. This will help to minimize the challenges related to the failure of non-financial BDS that were acquired to meet the company's needs and expectations. Additionally, professionals and Government agencies involved in the provision of BDS must be aware of the service requirements in order to avoid generalized training and business advisory services that are not optimal for businesses. Moreover, the Government needs to be aware of the types of support and policies that businesses need to advance private sector development. For example, unfriendly measures aimed at increasing tax revenues without taking into account the solvency of MSMEs create uncertainty and lower entrepreneurial spirit.

Study Limitations. This study used random sampling approach to identify MSMEs to participate in the study. As a result, 380 MSMEs were approached with questionnaires but only 250 MSMEs returned the questionnaire. A total of 250 MSMEs may not be a representative sample given a large number of firms operating under MSMEs both formally and informally in Dar es salaam region. Moreover, we used multiple regression analysis, while this approach is ideal for examining association of variables, it may not be appropriate for examining impacts. 
Future lines of research. The study proposes comparative studies across countries and regions on the impact of non-financial BDS on the firm performance and development. This is because there is a relatively large heterogeneity of the results among countries. Moreover, we suggest future lines of research to test how perceptions of the challenges of non-financial support services decrease MSMEs development and how the perceptions of the benefits of non-financial support services increase MSMEs development.

\section{References}

Abdullahi, M. S., Ghazali, P. L., Awang, Z., Mohd Tahir, I., \& Mat Ali Salim, N. A. (2015). The Effect of Finance, Infrastructure and Training on the Performance of Small and Medium Scale Enterprises ( SMEs ) in Nigeria. International Journal of Business and Technopreneurship, 5(3).

https://ijbt.unimap.edu.my/images/stories/Volume_5_No_3_Oct_2015/IJBT_Vol_5_Oct_2015_8_421-452.pdf

Abor, J., \& Quartey, P. (2010). Issues in SME Development in Ghana and South Africa. International Research Journal of Finance and Economics, 39, 218-228

Anderson, W. (2017). Factors affecting small \& medium enterprises (SMEs) startup and growth in Tanzania. The Pan-African Journal of Business Management, 1(1). https://journals.out.ac.tz/index.php/pajbm/article/view/309

Asafo-Adjei, S. (2015). The Impact of Business Development Services on Micro Enterprises in the Asante Akim South District of the Ashanti Region. (Doctoral dissertation).. School of Graduate Studies, Kwame Nkrumah University of Science and Technology, Kumasi

Banerjee, A. V., Breza, E., Duflo, E., \& Kinnan, C. (2017). Do Credit Constraints Limit Entrepreneurship? Heterogeneity in the Returns to Microfinance. SSRN Electronic Journal. https://doi.org/10.2139/ssrn.3126359

Beck, T., Demirguc-Kunt, A., \& Levine, R. (2005). SMEs, Growth, and Poverty: Cross-Country Evidence. Journal of Economic Growth, 10(3), 199-229. https://doi.org/10.1007/s10887-005-3533-5

Becker, G. S. (1975). Human Capital: A Theoretical Analysis with Special Reference to Education. Columbia University Press

Beyene, M. (2005). Enhancing the Competitiveness and Productivity of Small and Medium Scale Enterprises in Africa: An Analysis of Differential Roles of Governments. Africa Development, 27(2). https://doi.org/10.4314/ad.v27i2.22167

Bozeman, B., \& Feeney, M. K. (2007). Toward a Useful Theory of Mentoring. Administration \& Society, 39(6), 719-739. https://doi.org/10.1177/0095399707304119

Brijlal, P. (2011). Business Development Service: Addressing The Gap In The Western Cape, South Africa. International Business \& Economics Research Journal (IBER), 7(9). https://doi.org/10.19030/iber.v7i9.3292

Caniëls, M. C. J., \& Romijn, H. A. (2005). What works, and why, in business services provision for SME: insights from evolutionary theory. Managing Service Quality: An International Journal, 15(6), 591-608. https://doi.org/10.1108/09604520510634041

Cofie, O., Adeoti, A., Nkansah-Boadu, F., \& Awuah, E. (2010). Farmers perception and economic benefits of excreta use in southern Ghana. Resources, Conservation and Recycling, 55(2), 161-166. https://doi.org/10.1016/j.resconrec.2010.09.002

Cronje, G. J. J., Du, T. G. S., \& Motlatla, M. D. C. (2004). Introduction to business management (6th ed). Oxford University Press

Diao, X., Kweka, J., \& McMillan, M. (2018). Small firms, structural change and labor productivity growth in Africa: Evidence from Tanzania. World Development, 105, 400-415. https://doi.org/10.1016/j.worlddev.2017.12.016

Ernst and Young (2009). Provision of Consultancy service for the study on the promotion of SMEs In the Eastern African region. Consolidated Regional Report

Fielder, F. E. (1964). A contingency model of leadership performance. In L. Berkowitz (Ed.), Advances in experimental social psychology. Academic Press

Fowowe, B. (2017). Access to finance and firm performance: Evidence from African countries. Review of Development Finance, 7(1), 6-17. https://doi.org/10.1016/j.rdf.2017.01.006

Herrington, M., Kew, J., \& Kew, P. (2009). Global Entrepreneurship Monitor, South African Report 2009. https://www.gemconsortium.org/report/gem-south-africa-2009-report 
Hitchins, R. (2002). The role of government in BDS market development: a preliminary review for the International Labour Office (SEED)

Huang, T. C. (2001). The relation of training practices and organizational performance in small and medium size enterprises. Education + Training, 43(8/9), 437-444. https://doi.org/10.1108/00400910110411620

IFC (2010). Scaling-Up SME Access to Financial Servicesin the Developing World, G20, Seoul Summit, 2010. International Financial Corporation

Isaga, N. (2019). Start-up motives and challenges facing female entrepreneurs in Tanzania. International Journal of Gender and Entrepreneurship, 11(2), 102-119. https://doi.org/10.1108/IJGE-02-2018-0010

Jenkins, B., Akhalkatsi, A., Roberts, B., \& Gardiner, A. (2007). Business linkages : lessons, opportunities, and challenges

Juma, S. A., \& Said, F. A. (2016). SME Globalization-Tanzania Case Study. International Journal Advances in Social Science and Humanities, 4(6), 1-4. https://www.ijassh.com/index.php/IJASSH/article/view/236

Karadal, H., \& Saygin, M. $(2011,10)$. The Effect of Information Technology on Innovation Abilities: A Research on SMEs. Paper presented at International Conference on Eurasian Economies, Bishkek, Kyrgyzstan. https://doi.org/10.36880/C02.00309

Katua, N. T. (2014). The Role of SMEs in Employment Creation and Economic Growth in Selected Countries. International Journal of Education and Research, 2(12). https://www.ijern.com/journal/2014/December-2014/39.pdf

Keasey, K., \& Wastson, R. (1993). Small Firm Management. Oxford Publishing

Kongolo, M. (2010). Job creation versus job shedding and the role of SMEs in economic development. African Journal of Business Management, 4(11), 2288-2295

Krüger, L. P. (2011). The impact of black economic empowerment (BEE) on South African businesses: Focusing on ten dimensions of business performance. Southern African Business Review, 15(3)

Kweka, J., \& Sooi, F. (2020). Partnership for inclusive growth: Can linkages with large firms spur the growth of SMEs in Tanzania?. UNU-WIDER. https://doi.org/10.35188/UNU-WIDER/2020/859-7

Lozano-Reina, G., \& Sánchez Marín, G. (2019). Prácticas de recursos humanos y rendimiento empresarial: Explorando el modelo AMO en las PYME españolas. Small Business International Review, 3(1), 67-85. https://doi.org/10.26784/sbir.v3i1.175

Lwesya, F. (2021). SMEs' competitiveness and international trade in the era of Global Value Chains (GVCs) in Tanzania: An assessment and future challenges. Small Business International Review, 5(1), e325. https://doi.org/10.26784/sbir.v5i1.325

Lwesya, F., \& Ismail, I. J. (2021). Financial Development and Private Sector Investment in the post financial liberalisation era in Tanzania. Management Dynamics in the Knowledge Economy, 9(2), 241-256. http://www.managementdynamics.ro/index.php/journal/article/view/415

Mashenene, R. G., \& Rumanyika, J. (2014). Business Constraints and Potential Growth of Small and Medium Enterprises in Tanzania: A Review. European Journal of Business and Management, 6(32), 72-79. https://iiste.org/Journals/index.php/EJBM/article/view/16863

Matshonisa Seeletse, S., \& Tshepo MaseTshaba, M. (2016). How South African SMEs could escape 'the heavyweight knockouts'! Public and Municipal Finance, 5(2), 40-47. https://doi.org/10.21511/pmf.5(2).2016.04

Mbura, O. K., \& Merezia, W. B. (2015). Success and usefulness of business development services in Tanzania's SMEs market. Business Management Review, 18(2)

McKenzie, D. J. (2015). Identifying and spurring high-growth entrepreneurship: Experimental evidence from a business plan competition. World Bank Policy Research Working Paper, 7391. World Bank Group

Mengstie, B. (2016). Impact of Business Development Services on Performance of Micro and Small Enterprises in East Amhara Region of Ethiopia. European Journal of Business and Management, 8(4), 179-187. https://iiste.org/Journals/index.php/EJBM/article/view/28653

Miehlbradt, A. O., \& McVay, M. (2003, 09). Developing Commercial Markets for Business Development Services. Paper presented at BDS Primer, 4th annual BDS seminar

Ministry of Trade and Industry (2012). Annual survey of industrial production 2009: Statistical report. Dar es Salaam, Tanzania

Mkenda, B. K., \& Rand, J. (2020). Examining the Ability of Tanzanian Small and Medium Enterprises (SMEs) to Increase their Penetration into Export Markets. Business Management Review, 23(1), 9-102. https://bmr.udsm.ac.tz/index.php/bmr/article/view/120

Molina-García, A., Florido-Ruiz, B., Campos Valenzuela, M., \& Diéguez-Soto, J. (2020). The effect of family ownership and generation on financial literacy. Small Business International Review, 4(1), 1-15. https://doi.org/10.26784/sbir.v4i1.236

Mori, N. (2015). Access to Business Development Support Services and Performance of Youth-Owned Enterprises in Tanzania. Journal of Entrepreneurship, Management and Innovation, 11(2), 57-81. https://doi.org/10.7341/20151123 
Mpunga, H. S. (2016). Examining the Factors Affecting Export Performance for Small and Medium Enterprises (SMEs) in Tanzania. Journal of Economics and Sustainable Development, 7(6)

Musara, M. (2010). The role played by Business Development Services Providers (BDSs) in improving access to finance by start-up SMEs in the Buffalo City Municipality. (Doctoral dissertation).. Faculty of Management and Commerce, University of Fort Hare

Nkwabi, J. M., \& Fallon, J. (2020). Assessing the Factors Affecting the Effective Implementation of Supply Chain Management (SCM) In Food Manufacturing Small And Medium Enterprsises (SMEs) In Dar Es Salaam

Nyangarika, A. (2016). Social-Economic Constraints towards Women Business Growth in Tanzania. European Journal of Business and Management, 8(5), 130-139. https://iiste.org/Journals/index.php/EJBM/article/view/28670

O'Dwyer, M., Gilmore, A., \& Carson, D. (2009). Innovative marketing in SMEs: an empirical study. Journal of Strategic Marketing, 17(5), 383-396. https://doi.org/10.1080/09652540903216221

O'Sullivan, A., \& Sheffrin, S. M. (2007). Economics: Principles in action. Pearson Prentice Hall

Obeng, B. A., \& Blundel, R. K. (2015). Evaluating Enterprise Policy Interventions in Africa: A Critical Review of Ghanaian Small Business Support Services. Journal of Small Business Management, 53(2), 416-435. https://doi.org/10.1111/jsbm.12072

OECD (2017). Enhancing the Contribution of SMEs in a Global and Digitalised Economy. Organization for Economic Cooperation and Development, Meeting of The OECD Council at Ministerial Level. OECD

Okeyo, W., Gathungu, J., \& K'Obonyo, P. (2014). The Effect of Business Development Services on Performance of Small and Medium Manufacturing Enterprises in Kenya. International Journal of Business and Social Research, 4(6), 12-26. https://www.thejournalofbusiness.org/index.php/site/article/view/536

Olawale, F., \& Garwe, D. (2010). Obstacles to the growth of start-up SMEs in South Africa: A principal component analysis approach. African Journal of Business Management, 4(5), 729-738. https://academicjournals.org/journal/AJBM/article-abstract/A1AFDEC23302

Olomi, D. R. (2009). African Entrepreneurship and Small Business Development. Otme Company Limited

Ombi, N., Ambad, S. N. A., \& Bujang, I. (2018). The Effect of Business Development Services on Small Medium Enterprises (SMEs) Performance. International Journal of Academic Research in Business and Social Sciences, 8(3). https://doi.org/10.6007/IJARBSS/v8-i3/3910

Otieno, H., Olomi, D. R., \& Kiraka, R. (2013). Building sustainable business development services: Empirical evidence from Kenya. (Doctoral dissertation).. Strathmore University. http://hdl.handle.net/11071/3531

Owusu, W., Cudjoe, G. A., \& Poku, K. (2017). The Effect of Non-Financial Support Services on Small and Medium Enterprises ( SMEs ) Development in a Developing Economy. International Journal of Business, Humanities and Technology, 7(1). https://www.ijbhtnet.com/journal/index/534

Peel, D. (2004). Coaching and Mentoring in Small to Medium Sized Enterprises in the UK - factors that affect success and a possible solution. International Journal of Evidence Based Coaching and Mentoring, 2(1), 46-56. https://radar.brookes.ac.uk/radar/items/b2678aef-a503-4926-af4d-c4af04486944/1/

Price, D. P., Stoica, M., \& Boncella, R. J. (2013). The relationship between innovation, knowledge, and performance in family and non-family firms: an analysis of SMEs. Journal of Innovation and Entrepreneurship, 2(1), 14. https://doi.org/10.1186/2192-5372-2-14

Radipere, S., \& Van Scheers, L. (2014). Investigating whether a lack of marketing and managerial skills is the main cause of business failure in South Africa. South African Journal of Economic and Management Sciences, 8(4), 402-411. https://doi.org/10.4102/sajems.v8i4.1171

Raghavan, A. M. (2005, 09). Achieving coherent capacity of correlated MIMO channels in the low- power regime with non-flashy signaling schemes. Paper presented at IEEE International Symposium on Information Theory, Adelaide, Australia

Rogerson, C. M. (2006). The market development approach to SMME development: Implications for local government in South Africa. Urban Forum, 17(1), 54-78. https://doi.org/10.1007/BF02681258

Schoar, A. (2010). The Divide between Subsistence and Transformational Entrepreneurship. Innovation Policy and the Economy, 10, 57-81. https://doi.org/10.1086/605853

Schultz, T. W. (1961). Investment in Human Capital. The American Economic Review, 51(1), 1-17. https://www.jstor.org/stable/1818907

Swai, M. I. (2017). Factors affecting growth of small and medium agro-processing firms in Tanzania: a case of sunflower oil processors in Dodoma. (Doctoral dissertation).. The University of Dodoma. http://hdl.handle.net/20.500.12661/571

Taraki, S. A. (2019). The Role of SMEs in Capital Formation, Equitable Growth and Income Distribution in Developing Countries. International Journal of Science and Research (IJSR), 8(1). https://www.ijsr.net/get_abstract.php?paper_id=ART20194175 
Tillmar, M. (2016). The Lack of Business Dispute Resolution in East Africa: An Unresolved Impediment to SME Development? In L. Achtenhagen, \& E. Brundin (Eds.), Entrepreneurship and SME Management Across Africa (pp. 51-64). Springer. https://doi.org/10.1007/978-981-10-1727-8_4

UNCTAD (2020). Creating Business Linkages. A Policy Perspective

URT (2003). Small and Medium Enterprise (SME) Development Policy. Ministry of Industry and Trade von Broembsen, M., Wood, E., \& Herrington, M. (2005). Global Entrepreneurship Monitor: South African Report 2005. https://www.gemconsortium.org/report/gem-south-africa-2005-report

Vroom, V. H. (1964). Work and motivation. John Wiley \& Sons

Woldie, A., Leighton, P., \& Adesua, A. (2008). Factors influencing small and medium enterprises (SMEs): An exploratory study of owner/manager and firm characteristics. Banks and Bank Systems, 3(3) 